\title{
The Bone Marrow Microenvironment in Health and Myeloid Malignancy
}

\author{
Marta Galán-Díez, Álvaro Cuesta-Domínguez, and Stavroula Kousteni \\ Department of Physiology \& Cellular Biophysics, College of Physicians \& Surgeons, Columbia University, \\ New York, New York 10032 \\ Correspondence: sk2836@cumc.columbia.edu
}

\begin{abstract}
Hematopoietic stem cells (HSCs) interact dynamically with an intricate network of cells in the bone marrow (BM) microenvironment or niche. These interactions provide instructive cues that influence the production and lineage determination of different types of blood cells and maintenance of HSC quiescence. They also contribute to hematopoietic deregulation and hematological myeloid malignancies. Alterations in the BM niche are commonly observed in myeloid malignancies and contribute to the aberrant function of myelodysplastic and leukemia-initiating stem cells. In this work, we review how different components of the BM niche affect normal hematopoiesis, the molecular signals that govern this interaction, and how genetic changes in stromal cells or alterations in remodeled malignant BM niches contribute to myeloid malignancies. Understanding the intricacies between normal and malignant niches and their modulation may provide insights into developing novel therapeutics for blood disorders.
\end{abstract}

$\mathrm{O}$ ne of the critical and unique functions of the skeleton is to provide the anatomical spaces for maintaining and facilitating differentiation of hematopoietic progenitors and precursors. Emerging evidence from several studies shows that all these populations require a supportive stromal-cell microenvironment in the bone marrow $(\mathrm{BM})$ and that disruptions in this microenvironment can lead to aberrant hematopoiesis and even hematopoietic malignancies in mice. Nonhematopoietic cells in the BM and their secreted products provide cellular and molecular components that are critical for the regulation of hematopoiesis and affect the development and progression of hematological myeloid and lymphoid malignancies. This article will review the principal stromal-cell types and their signals that have been implicated as regulatory cellular components of the hematopoietic stem-cell (HSC) niche in health and in malignancy. These components not only illustrate the complexity of the functions of bone, but may also provide critical clues to novel therapeutic targets for HSC expansion in conditions of myeloablation or in cases of malignant transformation of HSCs in hematological cancers.

\section{BONE IS THE HOME OF HEMATOPOIESIS}

In adults, bone is the home of hematopoiesis and within it, BM is the main site of residence for HSCs, where they stand on top of a hierarchy

Editors: Gerard Karsenty and David T. Scadden

Additional Perspectives on Bone: A Regulator of Physiology available at www.perspectivesinmedicine.org

Copyright (C) 2018 Cold Spring Harbor Laboratory Press; all rights reserved; doi: 10.1101/cshperspect.a031328

Cite this article as Cold Spring Harb Perspect Med 2018;8:a031328 
M. Galán-Díez et al.

of multipotent progenitors that become progressively restricted to several committed precursors and/or single lineages that give rise to the different types of mature blood cells (Fig. 1) (Orkin 2000). Largely, all HSC activity has been shown to be confined within the lineage $(\mathrm{Lin})^{-/ \mathrm{lo}} / \mathrm{Scal}^{+} / \mathrm{c}^{-\mathrm{kit}^{\text {hi }}}$ (also known as LSK) HSC compartment (Spangrude et al. 1988).
Nevertheless, this compartment is comprised by a functionally heterogeneous cell population regarding self-renewal, life span, and differentiation. The current model of definitive hematopoiesis relies on the idea of two functionally different HSC populations: the long-term HSCs (LT-HSCs) that give rise to the other one, and the short-term HSCs (ST-HSCs). LT-

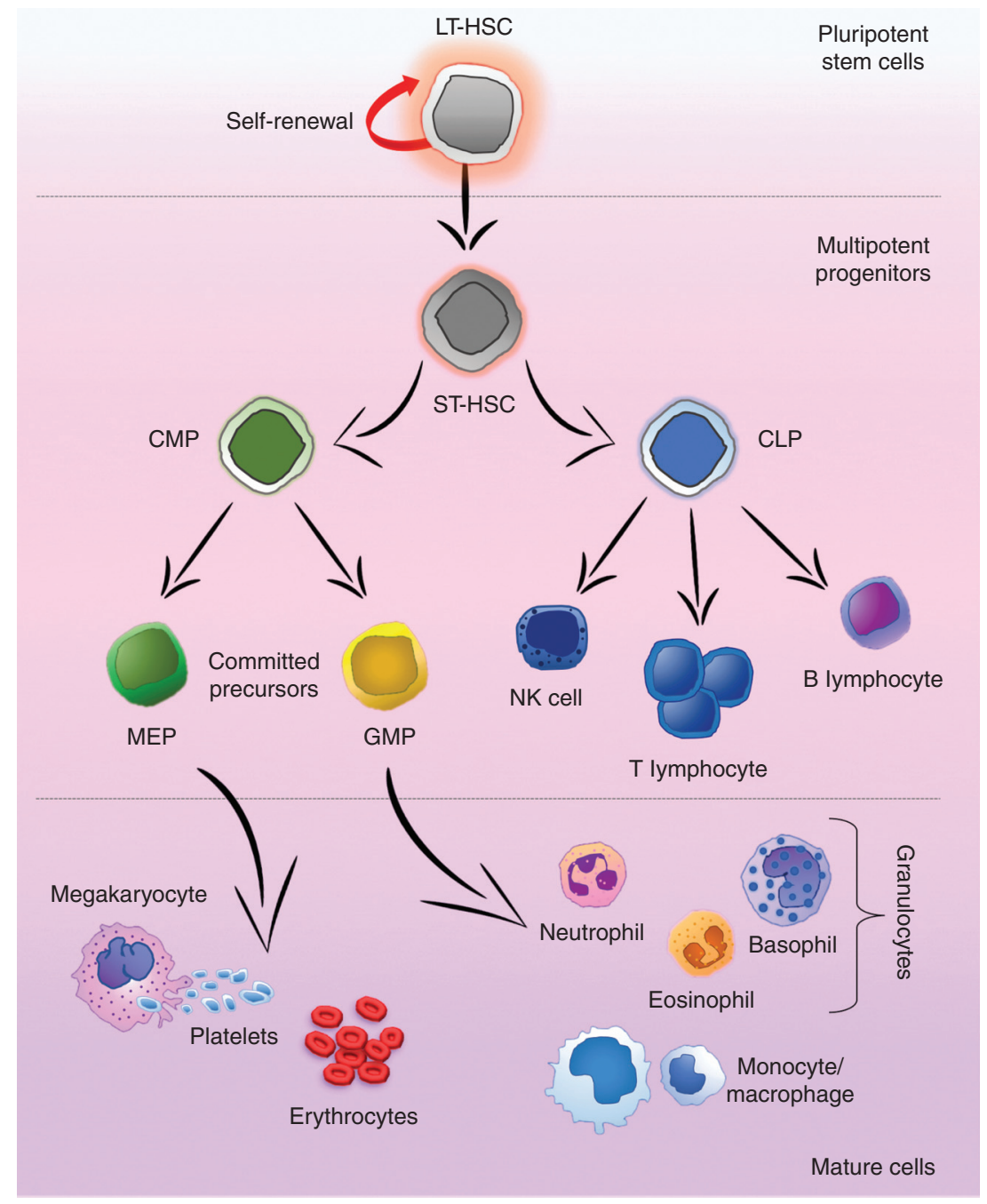

Figure 1. Hematopoiesis. The long-term reconstitution potential of the pluripotent long-term hematopoietic stem cells (LT-HSCs), can further differentiate toward the multipotent short-term (ST)-HSCs in the bone marrow (BM). Subsequent differentiation gives rise to either the common-lymphoid progenitors (CLPs), able to generate the complete lymphoid lineage (natural killer [NK] cells as well as B and T lymphocytes) or the common-myeloid progenitors (CMPs), which are able to differentiate into the myeloid lineage. Following these committed progenitors, both megakaryocyte/erythroid progenitors (MEPs) and granulocyte-macrophage progenitors (GMPs) are able to form all mature myeloid lineage cells in the BM. 
HSCs have lifelong self-renewing potential, whereas the ST-HSC-that show more restricted self-renewing capacity-produce common myeloid progenitors (CMPs) and common-lymphoid progenitors (CLPs) (Yang 2005). CLPs are the source of committed precursors of $\mathrm{B}$ and $\mathrm{T}$ lymphocytes, whereas CMPs give rise to megakaryocyte/erythroid progenitors (MEPs) and granulocyte-macrophage progenitors (GMPs) (Fig. 1). GMPs give rise to the committed precursors of mast cells, eosinophils, neutrophils, and macrophages. The different properties of these HSCs vary, probably reflecting diverse $\mathrm{BM}$ niches that support their expansion and/or differentiation as well as intrinsic characteristics at each stage.

\section{THE BONE MARROW NICHE}

The involvement of the BM niche in hematopoiesis emerged when it was suggested that HSCs reside and are regulated by a specialized BM microenvironment, the so-called niche (Schofield 1978). This concept implies that for hematopoiesis to take place, a specialized BM microenvironment needs to provide essential autocrine, endocrine, and paracrine signals as well as direct cell-to-cell interactions necessary for the ability of HSCs to self-renew and to differentiate into all blood-cell lineages. Many years of research have validated the niche concept, shedding light onto the molecular and cellular nature of the HSC niche in the BM, yet the exact contributions of the multiple cell types that comprise the BM niche are still under investigation. The BM microenvironment is not one niche but rather a collection of several "microniches" that create and at the same time are created by chemotactic gradients and distinct cell populations. Each of these microniches induces different responses in HSCs such as homing, mobilization, quiescence, self-renewal, or lineage commitment (Fig. 2).

\section{The Endosteal Niche}

In the adult $\mathrm{BM}$, under homeostatic conditions, HSCs reside very close to the endosteal bone surface (Lord et al. 1975; Gong 1978). Studies in mice have shown that, on transplantation, HSCs preferentially migrate to the endosteal region in close association with the bone-lining cells (Fig. 2) (Nilsson et al. 2001; Celso et al. 2009; Xie et al. 2009; Kim et al. 2017). Additionally, HSCs isolated from this region show higher proliferative potential as well as better long-term hematopoietic reconstitution potential (Haylock et al. 2007; Grassinger et al. 2010), whereas more differentiated hematopoietic progenitors are found mainly in the central BM region around the perivascular niche. The different cell types that comprise the endosteal niche are discussed below.

\section{Osteoblasts}

Osteoblasts are the main contributors of the endosteal niche and act as the first interface between the calcified bone and the BM. Cells of the osteoblast lineage were early identified as key cellular players in the control of hematopoiesis (Lord et al. 1975; Gong 1978; Taichman 1994; El-Badri et al. 1998). More recent studies suggest that osteoblast regulation of hematopoiesis may depend on their differentiation state (Sacchetti et al. 2007; Wu et al. 2008; Méndez-Ferrer et al. 2010; Calvi et al. 2012; Kunisaki et al. 2013; He et al. 2017).

In 2003, two studies provided the first evidence that cells of the osteoblast lineage regulate HSC self-renewal and expansion in vivo (Calvi et al. 2003; Zhang et al. 2003). Conditional deletion of the bone morphogenetic protein (BMP) receptor type IA or osteolineage-specific activation of parathyroid hormone (PTH) led to an increase in osteoblast numbers that correlated with increased HSC numbers. Nevertheless, alterations in the osteoblast lineage have also shown opposite effects, with some studies showing limited HSC expansion (Nilsson 2005; Stier et al. 2005). In fact, LT-HSCs isolated from osteoblast-ablated mice show reduced long-term engraftment and self-renewal capacity as well as loss of quiescence (Bowers et al. 2015). A decrease in osteoblast numbers favors myeloid but suppresses lymphoid and erythroid expansion (Krevvata et al. 2014). Interestingly, this shift to myeloid bias at the expense of lympho- 
M. Galán-Díez et al.

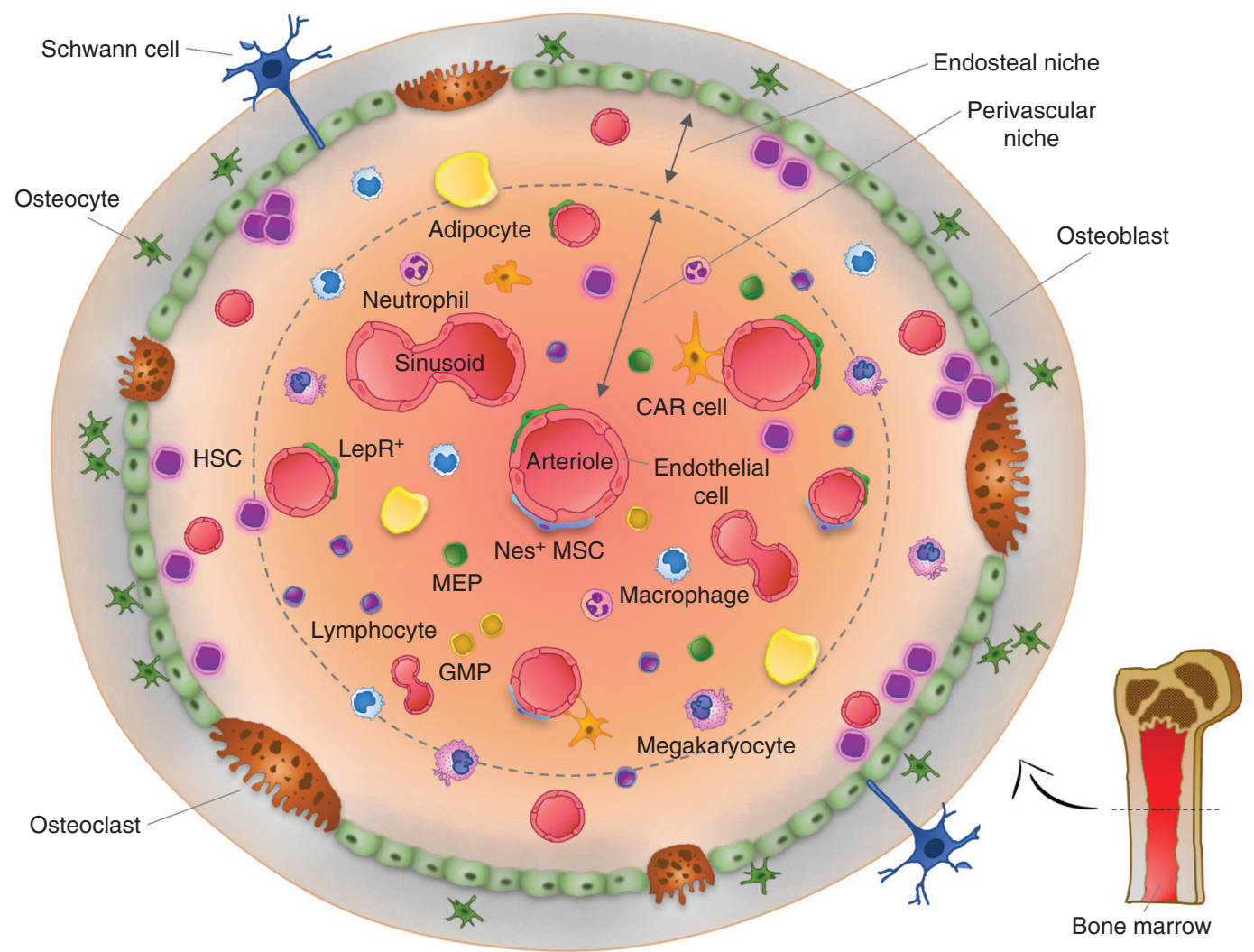

Figure 2. The bone marrow (BM) niche. Hematopoietic stem cells (HSCs) reside inside specialized microenvironments or niches within the BM. The organization of the BM niche and its association with HSCs are depicted within the two main niches: the endosteal and perivascular niche. The principal cell types of the endosteal niche are osteocytes, osteoblasts, and osteoclasts, with osteoblasts being the main cells supporting myelopoiesis throughout the release of soluble factors. Osteoblasts in the endosteal niche as well as endothelial cells, leptinreceptor-expressing perivascular cells $\left(\mathrm{LepR}^{+}\right), \mathrm{CXCL12}$-abundant reticular (CAR) cells, and Nestin ${ }^{+}$mesenchymal stem cells ( $\mathrm{Nes}^{+} \mathrm{MSCs}$ ) in the perivascular niche, secrete the CXC-chemokine ligand 12 (CXCL12), which controls HSC homing, retention, and repopulation of HSCs. Osteoblasts, Nestin ${ }^{+}$MSCs, and mainly perivascular cells release stem-cell factor (SCF), a key niche component that maintains the homing, retention and repopulation of HSCs.

poiesis, resembles characteristics of hematopoietic aging and may precondition the BM to easier engraftment and development of acute myeloid leukemia (AML) (Krevvata et al. 2014). Osteoblasts also appear to regulate HSC homing (Heissig et al. 2002). Studies in mice have shown that, upon transplantation, HSCs preferentially localize at the endosteal surface in close association with the bone-lining cells, whereas more differentiated progenitors localized mainly in the central marrow region around the perivascular niche (Fig. 2) (Nilsson et al. 2001; Zhang et al. 2003; Celso et al. 2009; Xie et al. 2009; Kim et al. 2017). HSCs found tightly adhered to the endosteal surface show higher proliferative and long-term engrafting potential (Haylock et al. 2007; Grassinger et al. 2010), In addition, cotransplantation of HSCs with osteoblasts increase their engraftment rate (El-Badri et al. 1998).

Several mechanisms may implement the cross talk between osteoblasts and HSCs in the endosteal niche. Osteoblasts produce several cytokines and growth factors that regulate HSC 
homing, mobilization, and quiescence, such as CXC-chemokine ligand 12 (CXCL12), stem-cell factor (SCF), osteopontin (OPN), granulocyte colony-stimulating factor (G-CSF), annexin 2 (ANXA2), angiopoietin 1 (ANG1), or thrombopoietin (TPO) (Taichman 1994; Ponomaryov et al. 2000; Calvi et al. 2003; Arai et al. 2004; Stier et al. 2005; Jung et al. 2007; Yoshihara et al. 2007). CXCL12 (or stromal-derived factor 1 [SDF-1]) is mainly produced by immature osteoblasts but also by endothelial cells and controls HSC homing, retention, and repopulation (Ponomaryov et al. 2000). Although SCF is mainly secreted by perivascular cells (Ding et al. 2012) and is a key component involved in HSC maintenance, osteoblasts are also contributing to its pool. Similarly, osteoblasts-as well as other cell types-secrete OPN, a glycoprotein matrix component that exerts a critical role in the retention, migration, and control of HSC proliferation and differentiation in the endosteal surface (Nilsson 2005; Stier et al. 2005; Grassinger et al. 2009). GCSF is necessary to support myelopoiesis and is mainly released by osteoblasts (Lord et al. 1975; Morad et al. 2008). ANXA2, highly expressed by both osteoblasts and endothelial cells, regulates HSC homing and engraftment (Jung et al. 2007). Osteoblast-expressed ANG1 interacts with TIE2 to promote HSC quiescence and adhesion (Puri and Bernstein 2003; Arai et al. 2004). Expression of TPO by osteoblasts has been involved in the regulation of LT-HSC quiescence (Yoshihara et al. 2007). A PTH-activated signaling pathway in osteoblasts simultaneously increases osteoblast numbers and HSC self-renewal and repopulating potential through Jagged-1 expression by osteoblasts and consequent Notch-1 activation in HSCs (Milner and Bigas 1999; Karanu et al. 2000; Calvi et al. 2003; Weber et al. 2006; Kode et al. 2016). A different study suggested that cellautonomous canonical Notch signals are not essential for HSC maintenance in vivo (Maillard et al. 2008). These results may indicate that activation of Notch signals in HSCs is induced by additional cells in the BM niche. Indeed, defective canonical Notch signaling in endothelial cells alters hematopoietic homeostasis leading to a myeloproliferative-like disease (Wang et al. 2014). More recently, mesenchymal stem cells
(MSCs) of the endosteal niche were shown to express distinct molecular profiles based on their proximity to HSCs (Goncalves et al. 2016; Silberstein et al. 2016). Those in closest proximity expressed three secreted or cell-surface molecules not previously connected to HSC biology: the RNase angiogenin, the cytokine interleukin (IL)-18, and the adhesion molecule embigin (Silberstein et al. 2016). All of these factors were found to be HSC quiescence regulators.

\section{Osteocytes}

Osteocytes-terminally differentiated osteoblasts-comprise $90 \%$ of mature bone cells. Osteocytes are embedded in the bone matrix and extend long projections to connect with surrounding osteocytes as well as bone-lining osteoblasts (Fig. 2). Given their anatomical location, the effect of osteocytes on the HSC pool may not be direct but rather through the endosteal osteoblasts. Osteocytes have been involved in the control of HSCs through the secretion (Fulzele et al. 2013) and responsiveness (Asada et al. 2013) to G-CSF. Disruption of Gs- $\alpha$ signaling in osteocytes leads to bone loss associated with an expansion of the myeloid lineage, in part through G-CSF osteocyte production (Fulzele et al. 2013). Ablation of osteocytes does not affect HSC numbers, but impairs the ability of HSCs to be mobilized in response to G-CSF (Asada et al. 2013). Osteocyte-specific activation of the PTH receptor 1 (PTHR1), despite expanding the osteoblast pool, was not enough to increase HSCs numbers nor their function (Calvi et al. 2012). Moreover, activation of $\beta$ catenin in osteocytes enhances components of the Notch signaling pathway, but does not alter hematopoiesis or survival (Tu et al. 2015).

\section{The Perivascular Niche}

Another HSC-supporting niche identified in close proximity to blood vessels in the adult $\mathrm{BM}$ is the perivascular niche, essential for gas exchange and delivery of nutrients and waste removal in the BM (Kiel et al. 2005). The associations between HSCs and perivascular and en- 
M. Galán-Díez et al.

dothelial stromal cells suggest that these cell populations coexist in an environment that promotes their maintenance and expansion. It has been proposed that dormant (quiescent) HSCs reside specifically in the proximity of arterioles preferentially found in the endosteal surface rather than sinusoids, suggesting that there are separate, spatially distinct perivascular niches for quiescent and proliferating HSCs in the BM (Kunisaki et al. 2013). Two recent studies using HSC-transgenic reporter mice revealed that, indeed, the majority of the quiescent HSCs are located in the perivascular niche, more closely associated with sinusoids and localized all along the marrow (Acar et al. 2015; Chen et al. 2016b). Similarly, a recent study using high-resolution in vivo imaging confirmed that HSCs preferentially interact with the perivascular niche (Koechlein et al. 2016). The perivascular niche itself is heterogeneous and contains distinct cell types discussed below.

\section{Endothelial Cells}

The blood vessels that deliver both oxygen and nutrients to cells and establish the perivascular niche are lined by the endothelial cells. HSCs, as well as hematopoietic progenitors, localize to these endothelial structures near the endosteal surface (Kiel et al. 2005). In vivo imaging of the BM niche shows HSCs in areas localized between closely located endothelial cells and endosteal osteoblasts, suggesting that both cell types might be essential components of a particular niche (Celso et al. 2009; Ellis et al. 2011). The endothelial cells regulate HSC fate both by direct cell-to-cell contact as well as by the secretion of angiocrine factors (Butler et al. 2010; Kobayashi et al. 2010). Despite the fact that specific deletion of SCF in endothelial cells did not result in loss of HSC function-suggesting that these cells may not directly support HSC populations (Ding and Morrison 2013) - the secretion of CXCL12, vascular endothelial growth factor A (VEGF-A), fibroblast growth factor 2 (FGF2), ANG1, thrombospondin-1 (TSP1), and Notch ligands, has been described to maintain the stem-cell pool and regulate self-renewal of HSCs (Butler et al. 2010; Kobayashi et al. 2010;
Poulos et al. 2013; Rafii et al. 2016). In fact, either arteriolar or sinusoidal cell populations may orchestrate mesenchymal populations found in their proximity, responsible for HSC support (Ding et al. 2012; Winkler et al. 2012; Kunisaki et al. 2013; Acar et al. 2015; Itkin et al. 2016).

\section{Leptin Receptor Perivascular-Expressing Cells}

The receptor for the fat-cell-specific hormone, leptin, is a well-established marker for MSCs. Indeed, $94 \%$ of colony-forming unit fibroblasts (CFU-Fs) in adult mouse BM are leptin-receptor-positive $\left(\mathrm{LepR}^{+}\right)$cells (Zhou et al. 2014). Both LepR ${ }^{+}$stromal cells and CXCL12-abundant reticular (CAR) cells (discussed below) are located mainly overlapping around the sinusoids and are crucial for HSC maintenance (Ding et al. 2012; Acar et al. 2015) and are the major source of growth factors (including CXCL12 and SCF) for the maintenance of HSCs (Ding et al. 2012; Ding and Morrison 2013). These stromal cells are responsible for the trilineage differentiation of MSCs into fat (adipocytes), bone (osteoblasts), and cartilage (chondrocytes) in the adult BM (Zhou et al. 2014). Of note, all of these studies were performed using noninducible Cre lines; therefore, they reflect the effects of lack of LepR in cells since development and not necessarily at the time analyzed.

\section{Nestin-Expressing Mesenchymal Stem Cells}

Nestin-positive $\left(\mathrm{Nes}^{+}\right)$cells, despite constituting a small fraction of the BM cells, contain all of the MSC activity of the marrow (Méndez-Ferrer et al. 2010). Moreover, these $\mathrm{Nes}^{+}$cells, confined in the perivascular region, colocalize with HSCs, and depletion of this population results in HSCmobilization (Méndez-Ferrer et al. 2010). $\mathrm{Nes}^{+}$ cells produce soluble factors involved in HSC maintenance, such as CXCL12 and SCF, leading to the hypothesis that MSCs form a niche with HSC directly and maintain HSC activity (Méndez-Ferrer et al. 2010). Interestingly, Nestin is expressed by Sca- $1^{+} / \mathrm{CD} 31^{\text {high }}$ arterial endothelial cells but not by Sca- $1^{-} / \mathrm{CD} 31^{+}$sinusoid endothelial cells (Itkin et al. 2016). The lower per- 
Bone Marrow in Health and Malignancy

meability of the arterioles was suggested to provide a "metabolically inactive" microenvironment that favors HSC quiescence (Itkin et al. 2016).

\section{CXCL12-Abundant Reticular Cells}

CAR cells are a subset of MSCs named for its high expression of CXCL12, a key factor for HSC proliferation (Omatsu et al. 2010). Most of the cells that express CXCL12 and are closely associated with the endothelial cells (Sugiyama et al. 2006), are also LepR ${ }^{+}$cells and, in fact, deletion of CXCL12 from LepR ${ }^{+}$cells and endothelial cells removes all quiescent and serially transplantable HSCs from adult BM.

\section{SYMPATHETIC NERVOUS SYSTEM NEURONAL CELLS AND GLIA}

The sympathetic nervous system (SNS) has emerged as a regulator of the HSC BM niche. Catecholamines-produced by sympathetic nerves-are delivered to the BM niche through the blood circulation or by secretion from the nerve endings acting in a paracrine mode (Kalinkovich et al. 2009). SNS affects the migration of HSCs from the BM to the bloodstream through direct actions on HSCs and also indirectly through the microenvironment (Spiegel et al. 2007; Kalinkovich et al. 2009). Osteoblastic cells in the BM can influence HSC egress through a process that is regulated by the SNS and involves suppression of CXCL12 production. Sympathectomy of one tibia in a mouse downregulates CXCL12 expression, without affecting the sham-operated contralateral and impairs HSC mobilization in response to G-CSF (Katayama et al. 2006; Méndez-Ferrer et al. 2008). Inhibition of CXCL12 may promote HSC migration by inducing critical pathways for cytokineinduced mobilization (Katayama et al. 2006; Christopher et al. 2009). Last, glial cells in the $\mathrm{BM}$ are closely associated with HSCs and produce several factors previously identified as playing a role in the HSC niche (Yamazaki et al. 2009, 2011). Glial cell ablation results in loss of HSC dormancy and ultimately of HSC numbers (Yamazaki et al. 2011).

\section{THE ROLE OF THE BONE MARROW NICHE IN HEMATOLOGICAL MYELOID MALIGNANCIES}

Deregulation of hematopoiesis is associated with the development of hematological malignancies. Emerging evidence shows that the BM microenvironment, with its intricate and dynamic network of distinct cell types that support and sustain hematopoiesis, plays a key role in the maintenance, initiation, or outcome of myeloid disorders. Some of the interactions between cells of the BM niche and cells of the hematopoietic compartment have been shown to be altered in malignant diseases, and several other mechanisms of interactions have been identified in a wide array of hematological disorders.

Interactions between Components of the BM Stromal Niche with Malignant Cells

Cells of the BM stromal niche are of particular interest for their role not only in regulating benign HSC functions but also their malignant counterparts. A series of studies have shown bidirectional, instructive signals between the two types of cell populations.

\section{Competition between HSCs and Leukemia Cells in the BM Niche}

Xenograft as well as syngeneic mouse models have shown that leukemic cells compete with benign HSCs for access to the HSC niche and disrupt normal interactions between HSCs and their microenvironment, thereby displacing HSCs and inhibiting hematopoiesis (Colmone et al. 2008; Glait-Santar et al. 2015). Interruption of such interactions between HSCs and their niche can protect leukemia cells from chemotherapy leading to relapse of the disease (Ishikawa et al. 2007; Lane et al. 2011). In models of AML, this protection can be abrogated by inhibition of the CXCL12/CXCR4 axis (Nervi et al. 2009; Zeng et al. 2009). Conversely, in models of acute lymphoblastic leukemia (ALL), it was shown that, following chemotherapy, residual leukemia cells persisted by residing in a specialized niche that was dependent on leukemic production of chemokine ligand 3 (CCL3) and 
M. Galán-Díez et al.

transforming growth factor (TGF)- $\beta 1$ (Duan et al. 2014).

\section{Molecular Signals from the BM Niche Affecting Leukemia}

Osteoblasts are emerging as important regulators of leukemia outcome. Ablation of osteoblastic cells was shown to accelerate leukemia progression in several mouse models of AML and ALL (Frisch et al. 2012; Krevvata et al. 2014). Maintenance of osteoblast numbers during leukemia by pharmacological inhibition of the synthesis of duodenal serotonin through treatment with the tryptophan-hydroxylase inhibitor LP533401, stimulated normal hematopoiesis, delayed disease engraftment, reduced tumor burden, and prolonged survival (Krevvata et al. 2014). More recently, the establishment of a human AML xenotransplant system into NSG mice by coinfusion of patient-derived MSCs (Reinisch et al. 2016) allowed the opportunity to study interactions between human leukemia cells and human stromal niche in vivo. Human MSCs were able to grow and undergo effective differentiation, forming a functional vascularized ossicle with a BM cavity that fully recapitulates its supportive function in vivo and enhances AML cell-engraftment efficiency.

\section{Metabolic Regulation of Leukemia Cells by the BM Niche}

The BM niche is hypoxic as has been indicated by increased oxygen tension in the BM or by increased expression of hypoxia-inducible factor (HIF) $-1 \alpha$ and hypoxia markers (Takubo et al. 2010; Spencer et al. 2014). Hypoxic conditions in the BM may affect the engraftment of leukemia cells as indicated by studies showing that silencing HIF-2 $\alpha$ in human AML cells decreased their engraftment in xenograft models (RouaultPierre et al. 2013). Consistent with these findings, the hypoxia-activated prodrug TH-302 efficiently depleted leukemia cells and prolonged survival of AML xenograft models (Benito et al. 2016), indicating that HIFs are required for leukemia cell maintenance. In contrast, conditional inactivation of HIF- $1 \alpha$ and HIF- $2 \alpha$ in mouse models of MEIS1/HOXA9- or MLL-AF9-driven leukemogenesis favored engraftment, indicating that HIF is a tumor suppressor in at least these models of AML initiation (Vukovic et al. 2015). Additional mouse models of AML and models of patient-derived xenografts (PDXs) are required to understand the involvement of different HIFs in AML. In contrast to HSCs, which use glycolysis for energy generation and to maintain quiescence, AML cells depend on oxidative phosphorylation for survival (Lagadinou et al. 2013). It appears that, to fulfill this need, AML cells uptake functional mitochondria from BM stromal cells through an endocytic pathway and that this uptake is enhanced by chemotherapeutic agents (Moschoi et al. 2016). This mitochondrial transfer may provide a survival advantage following chemotherapy.

\section{Neuropathy Induced by Malignant Cells Alters the BM Niche}

$\mathrm{Nes}^{+}$MSCs and osteoblasts appear to be targets of SNS signaling-dependent interactions with malignant cells in different models of myeloid malignancies. In an MLL-AF9-AML model, leukemia cells induce sympathetic neuropathy leading to aberrant expansion of $\mathrm{Nes}^{+}$MSCs while restricting the numbers of mature osteoblasts through $\beta 2$-adrenergic signaling (Hanoun et al. 2014). As a result, expression of HSC-retention factors, including CXCL12, SCF, ANG1, and VCAM1 was decreased. In a mouse model of myeloproliferative neoplasms (MPNs) harboring the JAK2V617F mutation, the production of IL- $1 \beta$ by mutant HSCs causes damage to sympathetic nerve fibers and death of Schwann cells, leading to loss of $\mathrm{Nes}^{+}$MSCs and decreased CXCL12 production (Arranz et al. 2014). In turn, the impaired niche promotes expansion of mutant HSCs and facilitates MPN progression. These events are prevented by treatment with agonists of $\beta 3$-adrenergic receptors, which are expressed in MSCs.

Leukemia-Initiating Mutations in the Stroma

Under certain conditions, osteolineage cells have been shown to function as leukemia-initi- 
ating cells. The first suggestion for a disease-initiating niche was provided by two studies showing that genetic ablation of retinoblastoma $(R b)$ or retinoic acid receptor $\gamma\left(\operatorname{Rar}_{\gamma}\right)$ in mice induced development of an MPN-like syndrome (Walkley et al. 2007a,b). However, MPN development required inactivation of either gene in both hematopoietic and nonhematopoietic cells. This type of HSC-extrinsic disorder shifted attention to the $\mathrm{BM}$ niche as a required component for the development of the MPN phenotype in both models. Shortly thereafter, another study linked a defective Notch signaling in nonhematopoietic cells to a de novo MPN (Kim et al. 2008). However, the specific identity of the disease-instigating cell(s) in the BM niche and whether these findings were relevant to patients remain unknown.

Cells of the osteoblast lineage were directly implicated in this process in a study showing that deletion of Dicer 1 in osterix-expressing osteoprogenitors (but not in mature osteoblasts) caused aberrant gene expression and led to myelodysplasia (MDS) in mice (Raaijmakers et al. 2010). This work pinpointed a model of nichebased oncogenesis in which primary alterations in the stroma would render a malignant microenvironment that could support further transformation events in distinct cell types (Fig. 3). In the same study, the observation that Dicer 1 inactivation in osteoprogenitors was associated with down-regulation of the expression of $S b d s$, mutations that cause Shwachman-Bodian-Diamond syndrome (a human BM failure and leukemia predisposition condition), provided an indirect first evidence that a perturbation in the stroma could be at the center of deregulated hematopoiesis in humans.

In a subsequent study, a mutation in osteoblasts that rendered $\beta$-catenin constitutively active $\left(C t n n b 1^{\text {CAosb }}\right)$, led to the development of MDS, rapidly developing to AML (Kode et al. 2014). The AML-like hematopoietic malignancy was shown to be completely dependent on overexpression of the Notch ligand Jagged-1 on osteoblastic cells followed by subsequent activation of Notch1-mediated signaling in LSK cells (Fig. 3). Overexpression of Jagged-1 in osteoblasts with activated $\beta$-catenin was because of its interaction with FoxO1 (Kode et al. 2016). This pathway leads to clonal expansion characterized by recurrent chromosomal aberrations and somatic mutations (Kode et al. 2014, 2016). As a result, AML can be transferred to healthy irradiated recipients. This pathway may be relevant to human disease because more than one-third of patients with MDS/AML showed nuclear accumulation of $\beta$-catenin (a readout of its constitutive activation), increased $\beta$-catenin signaling, and Jagged-1 expression in osteoblasts, as well as increased Notch signaling in MDS/AML cells. Interestingly, the fact that the phenotype was reversible in the mouse model by pharmacological targeting of the Notch pathway with a $\gamma$-secretase inhibitor may indicate a potential new therapeutic strategy for a subset of MDS and AML patients.

A more recent study examined the contribution of mutations in the stroma to hematological myeloid malignancies in the context of Noonan syndrome, a disorder that predisposes to the development of juvenile myelomonocytic leukemia (JMML), a childhood MPN (Dong et al. 2016). Noonan syndrome-activating mutations of the protein tyrosine phosphatase SHP2 in $\mathrm{Nes}^{+}$MSC led to the development of JMMLlike MPN by hyperactivating HSCs via overproduction of the CC-chemokine CCL3 and IL-1 $\beta$ (Fig. 3). Because Noonan syndrome is a disorder that involves alterations in several genes (RAS, CBL, B-RAF, SOS1, and SHOC2), a comprehensive study with a large cohort of patients could clarify the relevance of these findings to human disease.

Finally, another study examined the role of the niche in the concept of genotoxic stress-induced preleukemia. A Shwachman-Diamond syndrome mutation in stromal cells was shown to drive MDS in mice through an inflammatory axis that involves secretion by the stromal cells of the endogenous damage-associated molecular pattern (DAMP) molecules S100A8/9, and activation of Toll-like receptor (TLR) signaling in HSCs, driving oxidative stress and DNA-damage response (Fig. 3) (Zambetti et al. 2016). Notably, expression of S100A8/9 predicted the transformation of low-risk MDS patients to AML. Collectively, these observations 
M. Galán-Díez et al.

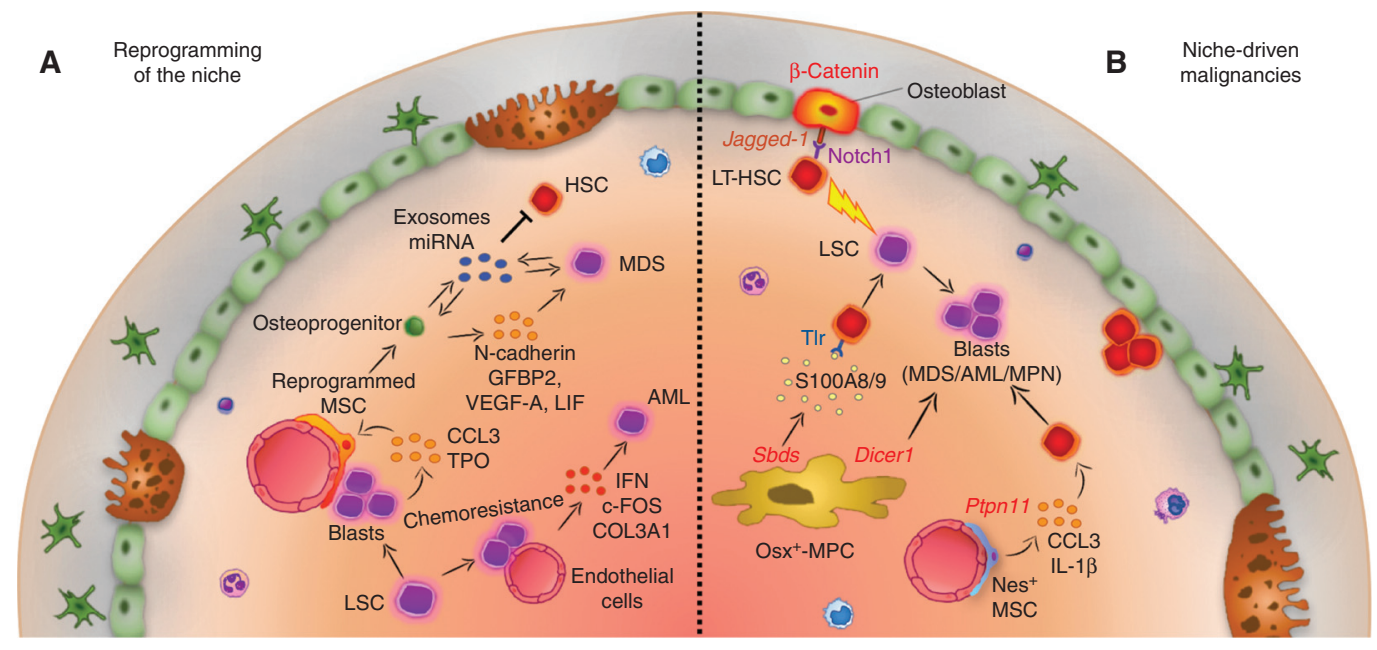

Figure 3. The role of the bone marrow (BM) niche in hematological malignancies. $(A)$ Reprogramming of the niche. Leukemic cells reprogram BM mesenchymal stem cells (MSCs) into a self-reinforcing leukemic microenvironment. Leukemia blasts promote osteoblast formation by MSCs through cell-to-cell contact and secretion of chemokine ligand 3 (CCL3) and thrombopoietin (TPO). Myelodysplasia (MDS) patient-derived MSCs instruct the stroma to secrete $\mathrm{N}$-cadherin, insulin-like growth factor-binding protein 2 (IGFBP2), vascular endothelial growth factor A (VEGF-A), and leukemia inhibitory factor (LIF), favoring MDS expansion. Exosomes containing microRNAs (miRNAs) are secreted and uptaken by MDS or BM stromal cells, impairing hematopoietic stem-cell (HSC) function, and favoring proliferation of dysplastic cells. Endothelial cells can protect and shelter acute myeloid leukemia (AML) cells from chemotherapy, while responding to them by up-regulation of c-FOS, interferon (IFN) signaling, and type III collagen A (COL3A). (B) Niche-driven malignancies. Mutations in niche components have been linked to initiation of myeloid malignancies: an activating mutation of $\beta$-catenin in osteoblasts induces AML in mice through up-regulation of Jagged-1 expression in the same cells. As a result, Notch1 signaling is activated in long-term HSCs (LT-HSCs). An activating mutation of the protein tyrosine phosphatase SHP2 (encoded by Ptpn11) in Nestin ${ }^{+}$MSC cells leads to the development of myeloproliferative neoplasm (MPN) by hyperactivating HSCs via overproduction of CCL3 and interleukin (IL)-1 $\beta$. A mutation in Dicer1 in osterix (Osx) ${ }^{+}$-mesenchymal progenitor cells (MPCs) deregulates global gene expression and leads to MDS. A Shwachman-Diamond syndrome ( $S b d s)$ mutation in the same cell type drives MDS in mice through secretion of the proinflammatory secreted proteins S100A8/9 and subsequent activation of Toll-like receptor (TLR) signaling in HSCs that become dysplastic and eventually transform to AML.

suggest that genetic alterations in osteoblasts, their progenitors, and other stromal-cell niche lineages can initiate a multistep pathway to MDS and progression to AML.

\section{Dysplastic Cells Remodel the Bone Marrow Stromal Niche}

More recently, emerging evidence indicates that leukemic and other types of myelodyspastic cells can remodel and shape the BM niche into a selfreinforcing leukemic microenvironment. The signals that emanate from the leukemia stem cells (LSCs) include a variety of cytokines and chemokines with proinflammatory and angio- genic properties such as CXCL12, VEGF, tumor necrosis factor (TNF)- $\alpha$, IL-1, IL-6, and IL-8 (Medyouf et al. 2014; Zambetti et al. 2016; Zhang et al. 2016). This concept of leukemiainitiating inflammation on the marrow niche was depicted by a study describing the use of an inducible double transgenic BCR-ABL mouse model of human chronic myelogenous leukemia (CML) to dissect the effects of MPNs on the niche. Leukemic cells are able to directly increase osteoblast production by MSCs through cell-to-cell contact and enhanced secretion of inflammatory mediators such as CCL3 and TPO (Fig. 3). As a result of this proinflammatory milieu, CML remodels the endosteal niche so as 
to reenforce and self-perpetuate the blast crisis (Schepers et al. 2013). In line with this concept, MDS patient-derived MSCs were able to instruct the stroma to overproduce $\mathrm{N}$-cadherin, insulin-like growth factor-binding protein 2 (IGFBP2), VEGF-A, and leukemia inhibitory factor (LIF); this, in turn, promoted MDS expansion (Medyouf et al. 2014). Of note, in this study cotransplantation of $\mathrm{CD} 34^{+}$cells together with patient-derived MSCs into the BM of NSG mice, exemplifies the possibility to use PDX models as a preclinical platform for personalized drug development.

Exosomes, cell-derived microvesicles of endocytic origin present in possibly all eukaryotic fluids, may be another means of tumor-induced remodeling of the BM stroma niche (Fig. 3). In vitro studies show that AML-cell-derived exosomes enriched with RNA can be uptaken by $\mathrm{BM}$ stromal and their uptake leads to secretion of growth factors by the stroma as well as suppression of the HSC-retention factors SCF and CXCL12 in the stroma (Huan et al. 2015; Huang et al. 2013, 2015). The latter could compromise normal HSC functions. Exosomes released from CML cells induce IL-8 production from BM stromal cells (Corrado et al. 2016). Uptake of chronic lymphocytic leukemia (CLL) exosomes by MSCs and endothelial cells ex vivo reprograms these cells to become tumor-supportive by enhancing leukemia-cell proliferation, releasing cytokines, and promoting angiogenesis also ex vivo (Paggetti et al. 2015). A reverse type of intercellular communication has also been reported: exosomes released from BM MSCs collected from MDS patients can transfer miR-10a and miR-15a to $\mathrm{CD} 34^{+}$cells in vitro and modify the expression of MDM2 and TP53 genes (Muntión et al. 2016). However, exosomal transfer still remains to be shown in vivo.

Endothelial cells and adipocytes can also be targets for remodeling by malignant cells. Although the function of endothelial cells in AML models is not affected, their molecular profiling indicates the development of a transcriptional signature characterized by up-regulation of c-FOS and senescence-related genes, including interferon signaling and COL3A1 (Fig. 3) (Pizzo et al. 2016). In a xenograft model,
AML cells localize to the vessels in which they become more quiescent, and they respond poorly to cytarabine, indicating that endothelial cells may serve as a sanctuary site for AML (Cogle et al. 2014). Once adjacent to the vessels, AML cells integrate in the endothelium to stimulate the production of the beneficial endotheliumlike cells. Indeed, inhibition of AML cell tethering to endothelial cells with tubulin-binding combretastatins, which degrade endothelial cells adhesion molecules rendered AML sensitive to chemotherapy (Bosse et al. 2016). Leukemia cells residing in gonadal adipose tissue induce lipolysis, which in turns promotes fatty-acid metabolism of leukemia cells and appears to confer to the resistance to chemotherapy LSCs (Ye et al. 2016). Last, hematopoietic clonal cells directly generate altered niche components in models of primary myelofibrosis, which is characterized by increased myeloid proliferation and progressive BM fibrosis (Verstovsek et al. 2016). In these models, neoplastic monocyte-derived fibrocytes produced collagen and fibronectin thereby directly contributing to the BM fibrosis.

\section{Bone Marrow Stromal Niche Changes in Patients with Hematological Myeloid Malignancies}

Although the phenotypic profile of cell-surface expression markers defining stromal MSCs in the BM niche does not change between healthy subjects and myeloid-malignancy patients, specific subpopulation numbers, functions, or molecular profiles appear to be altered. MDS and AML patients show a reduction in osteoblast numbers, reflecting a corresponding reduction in bone-formation rate without any changes in osteoclast numbers (Krevvata et al. 2014). This is in agreement with clinical reports of osteopenia or osteoporosis, owing to a decrease in osteoblast function, noted in newly diagnosed children or adults with acute leukemia (Shalet 1996; Haddy et al. 2001; Sala and Barr 2007; Fitter et al. 2008; Sinigaglia et al. 2008; El-Ziny et al. 2013). In several of these studies, improvement of disease burden following chemotherapy correlated with an increase in osteoblast activity and bone mass, despite whether corticosterone treatment was 
M. Galán-Díez et al.

also used (Crofton et al. 1998; Fitter et al. 2008; El-Ziny et al. 2013). In stromal cells from MDS/ AML patients, expression of cell-surface molecules involved in interaction with HSCs is decreased (Geyh et al. 2013), whereas the population of $\mathrm{CD}_{271^{+}}$MSCs, which favor blast expansion through up-regulation of CXCL12 is increased (Kim et al. 2015a). In addition, CFU activity and osteogenic differentiation are significantly impaired (Geyh et al. 2016).

Interestingly, increased expression of Jagged-1, the Notch ligand that is required for AML induction by constitutively active $\beta$-catenin signaling in osteoblasts (Kode et al. 2014), is frequently noted in BM stromal cells derived from MDS or AML patients. Overexpression of Jagged-1 AML-derived stroma, along with SCF down-regulation, underlined the decreased stromal hematopoietic support that impaired the frequency of long-term culture-initiating healthy CD $34^{+}$HSCs (Geyh et al. 2016). Similarly, Jagged-1 expression levels were increased in MDS MSCs, while production of SCF, Ang-1, and chemokines was reduced, indeed correlating with an MDS-dependent hypermethylation pattern of these MSCs and a compromised capacity to support HSCs (Geyh et al. 2013). MSCs from patients with newly diagnosed AML appeared to have been reprogrammed by leukemia cells to express decreased levels of cell-cyclerelated genes, and increased levels of Jagged-1 and CXCL12 that favor leukemogenesis (Kim et al. 2015a). Furthermore, niche composition correlated with clinical outcome because patients with higher numbers of primitive MSCs $\left(\mathrm{CD} 146^{+} / \mathrm{CD} 166^{-}\right)$showed earlier relapse. Similarly, xenograft models of MDS patient-derived cells showed that MDS cells reprogrammed MSCs by genetic or epigenetic alterations, so that MSCs maintained a strong hypoxia signature under normoxic conditions and overproduced N-cadherin, IGFBP2, VEGF-A, and LIF to promote expansion of MDS cells (Medyouf et al. 2014).

Studies have reported the presence of cytogenetic aberrations in BM MSCs from patients with AML, MDS, MPNs, or CML. In most of these studies, MSC chromosomal abnormalities are distinct from those in leukemia blasts from the same patient (Blau et al. 2007, 2011; LopezVillar et al. 2009; Klaus et al. 2010; Huang et al. 2015). Array-comparative genomic hybridization (aCGH) analysis in MSCs from MDS patients identified one cluster linked to MDS with $5 \mathrm{q}^{-}$syndrome (Lopez-Villar et al. 2009). A large number of patients with MDS (44\%) or AML (54\%) presented structural chromosomal aberrations in their MSCs, with most abnormalities observed in chromosome 1, 7, or 10 (Blau et al. 2007). Notably, patients with aberrations in MSCs were more likely to experience leukemia-related mortality, perhaps caused by chromosomal instability after chromosome loss in MSCs that could facilitate growth or even transformation of MDS cells. However, another study identified chromosomal abnormalities in only $5 \%$ of patients with MDS/AML (Kim et al. 2015b). In high-risk MDS patients, MSCs showed increased levels of CDKN2B associated with the induction of senescence in MSCs, altered DNA methylation status, and shorter telomeres when compared with healthy older control donors (Poloni et al. 2014). Aberrant methylation of the stroma may impair support for normal HSCs and hematopoiesis in favor of malignant cells. In low-risk MDS patients, MSCs showed distinct transcriptome profiles from their healthy controls characterized by increased expression of pathways involved in cellular stress and inflammation (Chen et al. 2016c).

In CML, MSCs isolated from BCR-ABL ${ }^{+}$ patients do not express the $t(9 ; 22)$ translocation (Jootar et al. 2006; Wöhrer et al. 2007). In contrast, MSCs at early passages from patients with BCR-ABL-negative MPN carried the JAK2V617F mutation in both MPN cells and MSCs (Pieri et al. 2008; Mercier et al. 2009; Bacher et al. 2010; Avanzini et al. 2014). However, other genetic abnormalities involving different chromosomes were identified in $17 \%$ of patients with BCR-ABL-negative MPN (Avanzini et al. 2014). Whole-exome sequencing of BM MSCs collected from AML patients at diagnosis, remission, and relapse identified a persistent mutation in the PLEC gene in one patient. $P L E C$ encodes the key cytoskeleton player pectin (von der Heide et al. 2017). RNA sequencing revealed deregulation of proteoglycans, adhe- 
sion molecules, and cytokines in BM MSCs collected from AML patients at diagnosis and suggested alterations involved in metabolic pathways, endocytosis, and transcriptional and epigenetic signatures. Last, in IDH1 and IDH2 mutant AML, leukemia blasts produce the oncometabolite R-2-hydroxyglutarate (R-2HG), which alters epigenetics and differentiation in leukemia cells and also activates the nuclear factor (NF) $-\kappa B$ pathway in MSCs (Chen et al. 2016a). Up-regulation of NF- $\kappa B$ signaling contributes to enhanced proliferation and resistance to chemotherapy of AML cells.

\section{CONCLUDING REMARKS}

The important role of the BM niche in hematopoietic regulation and in hematological myeloid malignancies is shown by continuously emerging studies. Distinct niches within the BM microenvironment can differentially affect both normal HSC function and malignant cell engraftment and fate. Separate niches provide support for distinct and separate populations of HSCs and or different potential HSC fates. Similarly, niches communicate with malignant cells by stimulating pathways that can affect malignant cell competition in the BM with normal HSCs, adhesion, and protected residence within specific niches, engraftment and quiescence, response to neurological signals, and signals from the hypoxic microenvironment. In a most recent line of research, it is now appreciated that genetic alterations in the stromal niche can initiate myeloid malignancies, and that the molecular signals involved are active, and in certain cases predictive of the outcome in human disease. Conversely, MDS and leukemic cells in myeloproliferative neoplastic models provide instructive signals that remodel osteoblasts in the endosteal BM niche and other stromal cells into a self-reinforcing malignant niche. Aside from the impact of these observations in understanding the pathogenesis of myeloid malignancies, understanding the molecular signals between BM stromal and malignant cells can hold a translational potential. Despite decades of research, MDS and AML remain largely recalcitrant to targeted therapy. Thus far, few of the identified mutations have been amenable to targeted therapies. Furthermore, targeted therapies in hematological malignancies have been limited by the evolution of malignant subclones containing resistant mutations, prompting a search for alternative targets that may be more stable. In this context, the fact that the abnormal niche can be fertile soil for disease development indicates that targeting and interrupting niche-enabled signaling pathways in myeloid malignancies may be a novel therapeutic strategy in this family of diseases.

\section{REFERENCES}

Acar M, Kocherlakota KS, Murphy MM, Peyer JG, Oguro H, Inra CN, Jaiyeola C, Zhao Z, Luby-Phelps K, Morrison SJ. 2015. Deep imaging of bone marrow shows non-dividing stem cells are mainly perisinusoidal. Nature 526: 126130.

Arai F, Hirao A, Ohmura M, Sato H, Matsuoka S, Takubo K, Ito K, Koh GY, Suda T. 2004. Tie2/angiopoietin-1 signaling regulates hematopoietic stem cell quiescence in the bone marrow niche. Cell 118: 149-161.

Arranz L, Sánchez-Aguilera A, Martín-Pérez D, Isern J, Langa X, Tzankov A, Lundberg P, Muntión S, Tzeng YS, Lai DM, et al. 2014. Neuropathy of haematopoietic stem cell niche is essential for myeloproliferative neoplasms. Nature 512: 78-81.

Asada N, Katayama Y, Sato M, Minagawa K, Wakahashi K, Kawano H, Kawano Y, Sada A, Ikeda K, Matsui T, et al. 2013. Matrix-embedded osteocytes regulate mobilization of hematopoietic stem/progenitor cells. Cell Stem Cell 12: 737-747.

Avanzini MA, Bernardo ME, Novara F, Mantelli M, Poletto V, Villani L, Lenta E, Ingo DM, Achille V, Bonetti E, et al. 2014. Functional and genetic aberrations of in vitro-cultured marrow-derived mesenchymal stromal cells of patients with classical Philadelphia-negative myeloprolifer ative neoplasms. Leukemia 28: 1742-1745.

Bacher U, Asenova S, Badbaran A, Zander AR, Alchalby H, Fehse B, Kröger N, Lange C, Ayuk F. 2010. Bone marrow mesenchymal stromal cells remain of recipient origin after allogeneic SCT and do not harbor the JAK2V617F mutation in patients with myelofibrosis. Clin Exp Med 10: $205-208$

Benito J, Ramirez MS, Millward NZ, Velez J, Harutyunyan KG, Lu H, Shi YX, Matre P, Jacamo R, Ma H, et al. 2016. Hypoxia-activated prodrug TH-302 targets hypoxic bone marrow niches in preclinical leukemia models. Clin Cancer Res 22: 1687-1698.

Blau O, Hofmann WK, Baldus CD, Thiel G, Serbent V, Schümann E, Thiel E, Blau IW. 2007. Chromosomal aberrations in bone marrow mesenchymal stroma cells from patients with myelodysplastic syndrome and acute myeloblastic leukemia. Exp Hematol 35: 221-229.

Blau O, Baldus CD, Hofmann W-K, Thiel G, Nolte F, Burmeister T, Türkmen S, Benlasfer O, Schümann E, Sin- 
M. Galán-Díez et al.

dram A, et al. 2011. Mesenchymal stromal cells of myelodysplastic syndrome and acute myeloid leukemia patients have distinct genetic abnormalities compared with leukemic blasts. Blood 118: 5583-5592.

Bosse RC, Wasserstrom B, Meacham A, Wise E, Drusbosky L, Walter GA, Chaplin DJ, Siemann DW, Purich DL, Cogle CR. 2016. Chemosensitizing AML cells by targeting bone marrow endothelial cells. Exp Hematol 44: 363377.e5.

Bowers M, Zhang B, Ho Y, Agarwal P, Chen CC, Bhatia R. 2015. Osteoblast ablation reduces normal long-term hematopoietic stem cell self-renewal but accelerates leukemia development. Blood 125: 2678-2688.

Butler JM, Nolan DJ, Vertes EL, Varnum-Finney B, Kobayashi H, Hooper AT, Seandel M, Shido K, White IA, Kobayashi M, et al. 2010. Endothelial cells are essential for the self-renewal and repopulation of notch-dependent hematopoietic stem cells. Stem Cell 6: 251-264.

Calvi LM, Adams GB, Weibrecht KW, Weber JM, Olson DP, Knight MC, Martin RP, Schipani E, Divieti P, Bringhurst FR, et al. 2003. Osteoblastic cells regulate the haematopoietic stem cell niche. Nature 425: 836-841.

Calvi LM, Bromberg O, Rhee Y, Weber JM, Smith JNP, Basil MJ, Frisch BJ, Bellido T. 2012. Osteoblastic expansion induced by parathyroid hormone receptor signaling in murine osteocytes is not sufficient to increase hematopoietic stem cells. Blood 119: 2489-2499.

Celso Lo C, Fleming HE, Wu JW, Zhao CX, Miake-Lye S, Fujisaki J, Côté D, Rowe DW, Lin CP, Scadden DT. 2009. Live-animal tracking of individual haematopoietic stem/ progenitor cells in their niche. Nature 457: 92-96.

Chen JY, Lai YS, Tsai HJ, Kuo CC, Yen BL, Yeh SP, Sun HS, Hung WC. 2016a. The oncometabolite R-2-hydroxyglutarate activates NF- $\mathrm{\kappa B}$-dependent tumor-promoting stromal niche for acute myeloid leukemia cells. Sci Rep $\mathbf{6}$ 32428.

Chen JY, Miyanishi M, Wang SK, Yamazaki S, Sinha R, Kao KS, Seita J, Sahoo D, Nakauchi H, Weissman IL. 2016b. Hoxb5 marks long-term haematopoietic stem cells and reveals a homogenous perivascular niche. Nature 530: 223-227.

Chen S, Zambetti NA, Bindels EMJ, Kenswill K, Mylona AM, Adisty NM, Hoogenboezem RM, Sanders MA, Cremers EMP, Westers TM, et al. 2016c. Massive parallel RNA sequencing of highly purified mesenchymal elements in low-risk MDS reveals tissue-context-dependent activation of inflammatory programs. Leukemia $\mathbf{3 0}$ 1938-1942.

Christopher MJ, Liu F, Hilton MJ, Long F, Link DC. 2009. Suppression of CXCL12 production by bone marrow osteoblasts is a common and critical pathway for cytokineinduced mobilization. Blood 114: 1331-1339.

Cogle CR, Goldman DC, Madlambayan GJ, Leon RP, Masri Al A, Clark HA, Asbaghi SA, Tyner JW, Dunlap J, Fan G, et al. 2014. Functional integration of acute myeloid leukemia into the vascular niche. Leukemia 28: 1978-1987.

Colmone A, Amorim M, Pontier AL, Wang S, Jablonski E, Sipkins DA. 2008. Leukemic cells create bone marrow niches that disrupt the behavior of normal hematopoietic progenitor cells. Science 322: 1861-1865.

Corrado C, Saieva L, Raimondo S, Santoro A, De Leo G, Alessandro R. 2016. Chronic myelogenous leukaemia exosomes modulate bone marrow microenvironment through activation of epidermal growth factor receptor. J Cell Mol Med 20: 1829-1839.

Crofton PM, Ahmed SF, Wade JC, Stephen R, Elmlinger MW, Ranke MB, Kelnar CJ, Wallace WH. 1998. Effects of intensive chemotherapy on bone and collagen turnover and the growth hormone axis in children with acute lymphoblastic leukemia. J Clin Endocrinol Metab 83: 31213129.

Ding L, Morrison SJ. 2013. Haematopoietic stem cells and early lymphoid progenitors occupy distinct bone marrow niches. Nature 495: 231-235.

Ding L, Saunders TL, Enikolopov G, Morrison SJ. 2012. Endothelial and perivascular cells maintain haematopoietic stem cells. Nature 481: 457-462.

Dong L, Yu W-M, Zheng H, Loh ML, Bunting ST, Pauly M, Huang G, Zhou M, Broxmeyer HE, Scadden DT, et al. 2016. Leukaemogenic effects of Ptpn11 activating mutations in the stem cell microenvironment. Nature 539: 304-308,

Duan CW, Shi J, Chen J, Wang B, Yu YH, Qin X, Zhou XC, Cai YJ, Li ZQ, Zhang F, et al. 2014. Leukemia propagating cells rebuild an evolving niche in response to therapy. Cancer Cell 25: 778-793.

El-Badri N, Wang BY, Good RA G. 1998. Osteoblasts promote engraftment of allogeneic hematopoietic stem cells. Exp Hematol 26: 110-116.

Ellis SL, Grassinger J, Jones A, Borg J, Camenisch T, Haylock D, Bertoncello I, Nilsson SK. 2011. The relationship between bone, hemopoietic stem cells, and vasculature. Blood 118: 1516-1524.

El-Ziny MA, Al-Tonbary YA, Salama OS, Bakr AA, Al-Marsafawy H, Elsharkawy AA. 2013. Low turnover bone disease in Egyptian children with acute leukemia. Hematology 10: 327-333.

Fitter S, Dewar AL, Kostakis P, To LB, Hughes TP, Roberts MM, Lynch K, Vernon-Roberts B, Zannettino ACW. 2008. Long-term imatinib therapy promotes bone formation in CML patients. Blood 111: 2538-2547.

Frisch BJ, Ashton JM, Xing L, Becker MW, Jordan CT, Calvi LM. 2012. Functional inhibition of osteoblastic cells in an in vivo mouse model of myeloid leukemia. Blood 119: 540-550.

Fulzele K, Krause DS, Panaroni C, Saini V, Barry KJ, Liu X, Lotinun S, Baron R, Bonewald L, Feng JQ, et al. 2013 Myelopoiesis is regulated by osteocytes through Gso-dependent signaling. Blood 121: 930-939.

Geyh S, Oz S, Cadeddu R-P, Fröbel J, Brückner B, Kündgen A, Fenk R, Bruns I, Zilkens C, Hermsen D, et al. 2013 Insufficient stromal support in MDS results from molecular and functional deficits of mesenchymal stromal cells. Leukemia 27: 1841-1851.

Geyh S, Rodríguez-Paredes M, Jäger P, Khandanpour C, Cadeddu RP, Gutekunst J, Wilk CM, Fenk R, Zilkens C, Hermsen D, et al. 2016. Functional inhibition of mesenchymal stromal cells in acute myeloid leukemia. Leukemia 30: 683-691.

Glait-Santar C, Desmond R, Feng X, Bat T, Chen J, Heuston E, Mizukawa B, Mulloy JC, Bodine DM, Larochelle A, et al. 2015. Functional niche competition between normal hematopoietic stem and progenitor cells and myeloid leukemia cells. Stem Cells 33: 3635-3642. 
Goncalves KA, Silberstein L, Li S, Severe N, Hu MG, Yang H, Scadden DT, Hu GF. 2016. Angiogenin promotes hematopoietic regeneration by dichotomously regulating quiescence of stem and progenitor cells. Cell 166: 894-906.

Gong JK. 1978. Endosteal marrow: A rich source of hematopoietic stem cells. Science 199: 1443-1445.

Grassinger J, Haylock DN, Storan MJ, Haines GO, Williams B, Whitty GA, Vinson AR, Be CL, Li S, Sørensen ES, et al. 2009. Thrombin-cleaved osteopontin regulates hemopoietic stem and progenitor cell functions through interactions with $\alpha 9 \beta 1$ and $\alpha 4 \beta 1$ integrins. Blood 114: 49-59.

Grassinger J, Haylock DN, Williams B, Olsen GH, Nilsson SK. 2010. Phenotypically identical hemopoietic stem cells isolated from different regions of bone marrow have different biologic potential. Blood 116: 3185-3196.

Haddy TB, Mosher RB, Reaman GH. 2001. Osteoporosis in survivors of acute lymphoblastic leukemia. Oncologist 6: 278-285.

Hanoun M, Zhang D, Mizoguchi T, Pinho S, Pierce H, Kunisaki Y, Lacombe J, Armstrong SA, Dührsen U, Frenette PS. 2014. Acute myelogenous leukemia-induced sympathetic neuropathy promotes malignancy in an altered hematopoietic stem cell niche. Cell Stem Cell 15: 365-375.

Haylock DN, Williams B, Johnston HM, Liu MCP, Rutherford KE, Whitty GA, Simmons PJ, Bertoncello I, Nilsson SK. 2007. Hemopoietic stem cells with higher hemopoietic potential reside at the bone marrow endosteum. Stem Cells 25: 1062-1069.

He Q, Scott Swindle C, Wan C, Flynn RJ, Oster RA, Chen D, Zhang F, Shu Y, Klug CA. 2017. Enhanced hematopoietic stem cell self-renewal-promoting ability of clonal primary mesenchymal stromal/stem cells versus their osteogenic progeny. Stem Cells 35: 473-484.

Heissig B, Hattori K, Dias S, Friedrich M, Ferris B, Hackett NR, Crystal RG, Besmer P, Lyden D, Moore MAS, et al. 2002. Recruitment of stem and progenitor cells from the bone marrow niche requires MMP-9 mediated release of kit-ligand. Cell 109: 625-637.

Huan J, Hornick NI, Shurtleff MJ, Skinner AM, Goloviznina NA, Roberts CT, Kurre P. 2013. RNA trafficking by acute myelogenous leukemia exosomes. Cancer Res 73: 918 929.

Huan J, Hornick NI, Goloviznina NA, Kamimae- Lanning AN, David LL, Wilmarth PA, Mori T, Chevillet JR, Narla A, Roberts CT, et al. 2015. Coordinate regulation of residual bone marrow function by paracrine trafficking of AML exosomes. Leukemia 29: 2285-2295.

Huang JC, Basu SK, Zhao X, Chien S, Fang M, Oehler VG, Appelbaum FR, Becker PS. 2015. Mesenchymal stromal cells derived from acute myeloid leukemia bone marrow exhibit aberrant cytogenetics and cytokine elaboration. Blood Cancer J 5: e302.

Ishikawa F, Yoshida S, Saito Y, Hijikata A, Kitamura H, Tanaka S, Nakamura R, Tanaka T, Tomiyama H, Saito $\mathrm{N}$, et al. 2007. Chemotherapy-resistant human AML stem cells home to and engraft within the bone-marrow endosteal region. Nat Biotechnol 25: 1315-1321.

Itkin T, Gur-Cohen S, Spencer JA, Schajnovitz A, Ramasamy SK, Kusumbe AP, Ledergor G, Jung Y, Milo I, Poulos MG, et al. 2016. Distinct bone marrow blood vessels differentially regulate haematopoiesis. Nature 532: 1-19.
Jootar S, Pornprasertsud N, Petvises S, Rerkamnuaychoke B, Disthabanchong S, Pakakasama S, Ungkanont A, Hongeng S. 2006. Bone marrow derived mesenchymal stem cells from chronic myeloid leukemia $t(9 ; 22)$ patients are devoid of Philadelphia chromosome and support cord blood stem cell expansion. Leukemia Res 30: 1493-1498.

Jung Y, Wang J, Song J, Shiozawa Y, Wang J, Wang J, Havens A, Wang Z, Sun YX, Emerson SG, et al. 2007. Annexin II expressed by osteoblasts and endothelial cells regulates stem cell adhesion, homing, and engraftment following transplantation. Blood 110: 82-90.

Kalinkovich A, Spiegel A, Shivtiel S, Kollet O, Jordaney N, Piacibello W, Lapidot T. 2009. Blood-forming stem cells are nervous: Direct and indirect regulation of immature human $\mathrm{CD} 34^{+}$cells by the nervous system. Brain Behav Immun 23: 1059-1065.

Karanu FN, Murdoch B, Gallacher L, Wu DM, Koremoto M, Sakano S, Bhatia M. 2000. The notch ligand jagged-1 represents a novel growth factor of human hematopoietic stem cells. J Exp Med 192: 1365-1372.

Katayama Y, Battista M, Kao WM, Hidalgo A, Peired AJ, Thomas SA, Frenette PS. 2006. Signals from the sympathetic nervous system regulate hematopoietic stem cell egress from bone marrow. Cell 124: 407-421.

Kiel MJ, Yilmaz ÖH, Iwashita T, Yilmaz OH, Terhorst C, Morrison SJ. 2005. SLAM family receptors distinguish hematopoietic stem and progenitor cells and reveal endothelial niches for stem cells. Cell 121: 1109-1121.

Kim YW, Koo BK, Jeong HW, Yoon MJ, Song R, Shin J, Jeong DC, Kim SH, Kong YY. 2008. Defective Notch activation in microenvironment leads to myeloproliferative disease. Blood 112: 4628-4638.

Kim JA, Shim JS, Lee GY, Yim HW, Kim TM, Kim M, Leem SH, Lee JW, Min CK, Oh IH. 2015a. Microenvironmental remodeling as a parameter and prognostic factor of heterogeneous leukemogenesis in acute myelogenous leukemia. Cancer Res 75: 2222-2231.

Kim Y, Jekarl DW, Kim J, Kwon A, Choi H, Lee S, Kim YJ, Kim HJ, Kim Y, Oh IH, et al. 2015b. Genetic and epigenetic alterations of bone marrow stromal cells in myelodysplastic syndrome and acute myeloid leukemia patients. Stem Cell Res 14: 177-184.

Kim S, Lin L, Brown GAJ, Hosaka K, Scott EW. 2017. Extended time-lapse in vivo imaging of tibia bone marrow to visualize dynamic hematopoietic stem cell engraftment. Leukemia 89: 4013.

Klaus M, Stavroulaki E, Kastrinaki MC, Fragioudaki P, Giannikou K, Psyllaki M, Pontikoglou C, Tsoukatou D, Mamalaki C, Papadaki HA. 2010. Reserves, functional, immunoregulatory, and cytogenetic properties of bone marrow mesenchymal stem cells in patients with myelodysplastic syndromes. Stem Cells Dev 19: 1043-1054.

Kobayashi H, Butler JM, O'Donnell R, Kobayashi M, Ding BS, Bonner B, Chiu VK, Nolan DJ, Shido K, Benjamin L, et al. 2010. Angiocrine factors from Akt-activated endothelial cells balance self-renewal and differentiation of haematopoietic stem cells. Sci Rep 12: 1046-1056.

Kode A, Manavalan JS, Mosialou I, Bhagat G, Rathinam CV, Luo N, Khiabanian H, Lee A, Murty VV, Friedman R, et al. 2014. Leukaemogenesis induced by an activating $\beta$ catenin mutation in osteoblasts. Nature 506: 240-244. 
M. Galán-Díez et al.

Kode A, Mosialou I, Manavalan SJ, Rathinam CV, Friedman RA, Teruya-Feldstein J, Bhagat G, Berman E, Kousteni S. 2016. FoxO1-dependent induction of acute myeloid leukemia by osteoblasts in mice. Leukemia 30: 1-13.

Koechlein CS, Harris JR, Lee TK, Weeks J, Fox RG, Zimdahl B, Ito T, Blevins A, Jung SH, Chute JP, et al. 2016. Highresolution imaging and computational analysis of haematopoietic cell dynamics in vivo. Nature Commun 7: 12169.

Krevvata M, Silva BC, Manavalan IS, Galán-Díez M, Kode A Matthews BG, Park D, Zhang CA, Galili N, Nickolas TL, et al. 2014. Inhibition of leukemia cell engraftment and disease progression in mice by osteoblasts. Blood 124: 2834-2846.

Kunisaki Y, Bruns I, Scheiermann C, Ahmed J, Pinho S, Zhang D, Mizoguchi T, Wei Q, Lucas D, Ito K, et al. 2013. Arteriolar niches maintain haematopoietic stem cell quiescence. Nature 502: 637-643.

Lagadinou ED, Sach A, Callahan K, Rossi RM, Neering SJ, Minhajuddin M, Ashton JM, Pei S, Grose V, O’Dwyer KM, et al. 2013. BCL-2 inhibition targets oxidative phosphorylation and selectively eradicates quiescent human leukemia stem cells. Cell Stem Cell 12: 329-341.

Lane SW, Wang YJ, Celso Lo C, Ragu C, Bullinger L, Sykes SM, Ferraro F, Shterental S, Lin CP, Gilliland DG, et al. 2011. Differential niche and Wnt requirements during acute myeloid leukemia progression. Blood 118: 28492856.

Lopez-Villar O, Garcia JL, Sanchez-Guijo FM, Robledo C, Villaron EM, Hernández-Campo $\mathrm{P}$, Lopez-Holgado $\mathrm{N}$ Diez-Campelo M, Barbado MV, Perez-Simon JA, et al. 2009. Both expanded and uncultured mesenchymal stem cells from MDS patients are genomically abnormal, showing a specific genetic profile for the $5 \mathrm{q}^{-}$syndrome. Leukemia 23: 664-672.

Lord BI, Testa NG, Hendry JH. 1975. The relative spatial distributions of CFUs and CFUc in the normal mouse femur. Blood 46: 65-72.

Maillard I, Koch U, Dumortier A, Shestova O, Xu L, Sai H, Pross SE, Aster JC, Bhandoola A, Radtke F, et al. 2008. Canonical notch signaling is dispensable for the maintenance of adult hematopoietic stem cells. Cell Stem Cell 2 356-366.

Medyouf H, Mossner M, Jann J-C, Nolte F, Raffel S, Herrmann C, Lier A, Eisen C, Nowak V, Zens B, et al. 2014 Myelodysplastic cells in patients reprogram mesenchymal stromal cells to establish a transplantable stem cell niche disease unit. Cell Stem Cell 14: 824-837.

Méndez-Ferrer S, Lucas D, Battista M, Frenette PS. 2008 Haematopoietic stem cell release is regulated by circadian oscillations. Nature 452: 442-447.

Méndez-Ferrer S, Michurina TV, Ferraro F, Mazloom AR, Macarthur BD, Lira SA, Scadden DT, Ma'ayan A, Enikolopov GN, Frenette PS. 2010. Mesenchymal and haematopoietic stem cells form a unique bone marrow niche. Nature 466: 829-834.

Mercier F, Monczak Y, FranCois M, Prchal J, Galipeau J. 2009. Bone marrow mesenchymal stromal cells of patients with myeloproliferative disorders do not carry the JAK2-V617F mutation. Exp Hematol 37: 416-420.

Milner LA, Bigas A. 1999. Notch as a mediator of cell fate determination in hematopoiesis: Evidence and speculation. Blood 93: 2431-2448.
Morad V, Pevsner-Fischer M, Barnees S, Samokovlisky A, Rousso-Noori L, Rosenfeld R, Zipori D. 2008. The myelopoietic supportive capacity of mesenchymal stromal cells is uncoupled from multipotency and is influenced by lineage determination and interference with glycosylation. Stem Cells 26: 2275-2286.

Moschoi R, Imbert V, Nebout M, Chiche J, Mary D, Prebet T, Saland E, Castellano R, Pouyet L, Collette Y, et al. 2016 Protective mitochondrial transfer from bone marrow stromal cells to acute myeloid leukemic cells during chemotherapy. Blood 128: 253-264.

Muntión S, Ramos TL, Diez-Campelo M, Rosón B, SánchezAbarca LI, Misiewicz-Krzeminska I, Preciado S, Sarasquete ME, las Rivas de J, González M, et al. 2016. Microvesicles from mesenchymal stromal cells are involved in HPC-microenvironment crosstalk in myelodysplastic patients. PLoS ONE 11: e0146722.

Nervi B, Ramirez P, Rettig MP, Uy GL, Holt MS, Ritchey JK, Prior JL, Piwnica-Worms D, Bridger G, Ley TJ, et al. 2009. Chemosensitization of acute myeloid leukemia (AML) following mobilization by the CXCR4 antagonist AMD3100. Blood 113: 6206-6214.

Nilsson SK. 2005. Osteopontin, a key component of the hematopoietic stem cell niche and regulator of primitive hematopoietic progenitor cells. Blood 106: 1232-1239.

Nilsson SK, Johnston HM, Coverdale JA. 2001. Spatial localization of transplanted hemopoietic stem cells: Inferences for the localization of stem cell niches. Blood 97: 2293 2299.

Omatsu Y, Sugiyama T, Kohara H, Kondoh G, Fujii N, Kohno K, Nagasawa T. 2010. The essential functions of adipo-osteogenic progenitors as the hematopoietic stem and progenitor cell niche. Immunity 33: 387-399.

Orkin SH. 2000. Diversification of haematopoietic stem cells to specific lineages. Nat Rev Genet 1: 57-64.

Paggetti J, Haderk F, Seiffert M, Janji B, Distler U, Ammerlaan W, Kim YJ, Adam J, Lichter P, Solary E, et al. 2015 Exosomes released by chronic lymphocytic leukemia cells induce the transition of stromal cells into cancer-associated fibroblasts. Blood 126: 1106-1117.

Pieri L, Guglielmelli P, Bogani C, Bosi A, Vannucchi AM; Myeloproliferative Disorders Research Consortium (MPD-RC). 2008. Mesenchymal stem cells from JAK2 ${ }^{\mathrm{V} 617}$ mutant patients with primary myelofibrosis do not harbor JAK2 mutant allele. Leukemia Res 32: 516-517.

Pizzo RJ, Azadniv M, Guo N, Acklin J, Lacagnina K, Coppage M, Liesveld JL. 2016. Phenotypic, genotypic, and functional characterization of normal and acute myeloid leukemia-derived marrow endothelial cells. Exp Hematol 44: 378-389.

Poloni A, Maurizi G, Mattiucci D, Amatori S, Fogliardi B, Costantini B, Mariani M, Mancini S, Olivieri A, Fanelli M, et al. 2014. Overexpression of CDKN2B (p15INK4B) and altered global DNA methylation status in mesenchymal stem cells of high-risk myelodysplastic syndromes. Leukemia 28: 2241-2244.

Ponomaryov T, Peled A, Petit I, Taichman RS, Habler L, Sandbank J, Arenzana-Seisdedos F, Magerus A, Caruz A, Fujii N, et al. 2000. Induction of the chemokine stromal-derived factor-1 following DNA damage improves human stem cell function. J Clin Invest 106: 1331-1339. 
Poulos MG, Guo P, Kofler NM, Pinho S, Gutkin MC, Tikhonova A, Aifantis I, Frenette PS, Kitajewski J, Rafii S, et al. 2013. Endothelial Jagged-1 is necessary for homeostatic and regenerative hematopoiesis. Cell Rep 4: 1022-1034.

Puri MC, Bernstein A. 2003. Requirement for the TIE family of receptor tyrosine kinases in adult but not fetal hematopoiesis. Proc Natl Acad Sci 100: 12753-12758.

Raaijmakers MHGP, Mukherjee S, Guo S, Zhang S, Kobayashi T, Schoonmaker JA, Ebert BL, Al-Shahrour F, Hasserjian RP, Scadden EO, et al. 2010. Bone progenitor dysfunction induces myelodysplasia and secondary leukaemia. Nature 464: 852-857.

Rafii S, Butler JM, Ding BS. 2016. Angiocrine functions of organ-specific endothelial cells. Nature 529: 316-325.

Reinisch A, Thomas D, Corces MR, Zhang X, Gratzinger D, Hong WJ, Schallmoser K, Strunk D, Majeti R. 2016. A humanized bone marrow ossicle xenotransplantation model enables improved engraftment of healthy and leukemic human hematopoietic cells. Nat Med 22: 812-821.

Rouault-Pierre K, Lopez-Onieva L, Foster K, Anjos-Afonso F, Lamrissi-Garcia I, Serrano-Sanchez M, Mitter R, Ivanovic Z, de Verneuil H, Gribben J, et al. 2013. HIF-2 $\alpha$ protects human hematopoietic stem/progenitors and acute myeloid leukemic cells from apoptosis induced by endoplasmic reticulum stress. Cell Stem Cell 13: 549-563.

Sacchetti B, Funari A, Michienzi S, Di Cesare S, Piersanti S, Saggio I, Tagliafico E, Ferrari S, Robey PG, Riminucci M, et al. 2007. Self-renewing osteoprogenitors in bone marrow sinusoids can organize a hematopoietic microenvironment. Cell 131: 324-336.

Sala A, Barr RD. 2007. Osteopenia and cancer in children and adolescents: The fragility of success. Cancer 109: $1420-1431$.

Schepers K, Pietras EM, Reynaud D, Flach J, Binnewies M, Garg T, Wagers AJ, Hsiao EC, Passegué E. 2013. Myeloproliferative neoplasia remodels the endosteal bone marrow niche into a self-reinforcing leukemic niche. Cell Stem Cell 13: 285-299.

Schofield R. 1978. The relationship between the spleen colony-forming cell and the haemopoietic stem cell. Blood Cells 4: 7-25.

Shalet SM. 1996. Endocrine sequelae of cancer therapy. Eur J Endocrinol 135: 135-143.

Silberstein L, Goncalves KA, Kharchenko PV, Turcotte R, Kfoury Y, Mercier F, Baryawno N, Severe N, Bachand J, Spencer JA, et al. 2016. Proximity-based differential single-cell analysis of the niche to identify stem/progenitor cell regulators. Cell Stem Cell 19: 530-543.

Sinigaglia R, Gigante C, Bisinella G, Varotto S, Zanesco L, Turra S. 2008. Musculoskeletal manifestations in pediatric acute leukemia. J Pediatr Orthop 28: 20-28.

Spangrude GJ, Heimfeld S, Weissman IL. 1988. Purification and characterization of mouse hematopoietic stem cells. Science 241: 58-62.

Spencer JA, Ferraro F, Roussakis E, Klein A, Wu J, Runnels JM, Zaher W, Mortensen LJ, Alt C, Turcotte R, et al. 2014. Direct measurement of local oxygen concentration in the bone marrow of live animals. Nature 508: 269-273.

Spiegel A, Shivtiel S, Kalinkovich A, Ludin A, Netzer N, Goichberg P, Azaria Y, Resnick I, Hardan I, Ben-Hur H, et al. 2007. Catecholaminergic neurotransmitters regulate migration and repopulation of immature human CD $34^{+}$ cells through Wnt signaling. Nat Immunol 8: 1123-1131.

Stier S, Ko Y, Forkert R, Lutz C, Neuhaus T, Grünewald E, Cheng T, Dombkowski D, Calvi LM, Rittling SR, et al. 2005. Osteopontin is a hematopoietic stem cell niche component that negatively regulates stem cell pool size. J Exp Med 201: 1781-1791.

Sugiyama T, Kohara H, Noda M, Nagasawa T. 2006. Maintenance of the hematopoietic stem cell pool by CXCL12CXCR4 chemokine signaling in bone marrow stromal cell niches. Immunity 25: 977-988.

Taichman RS. 1994. Human osteoblasts support hematopoiesis through the production of granulocyte colony-stimulating factor. J Exp Med 179: 1677-1682.

Takubo K, Goda N, Yamada W, Iriuchishima H, Ikeda E, Kubota Y, Shima H, Johnson RS, Hirao A, Suematsu M, et al. 2010. Regulation of the HIF-1 $\alpha$ level is essential for hematopoietic stem cells. Cell Stem Cell 7: 391-402.

Tu X, Delgado-Calle J, Condon KW, Maycas M, Zhang H, Carlesso N, Taketo MM, Burr DB, Plotkin LI, Bellido T. 2015. Osteocytes mediate the anabolic actions of canonical Wnt/ $\beta$-catenin signaling in bone. Proc Natl Acad Sci 112: E478-86.

Verstovsek S, Manshouri T, Pilling D, Bueso-Ramos CE, Newberry KJ, Prijic S, Knez L, Bozinovic K, Harris DM, Spaeth EL, et al. 2016. Role of neoplastic monocyte-derived fibrocytes in primary myelofibrosis. J Exp Med 213: 1723-1740.

von der Heide EK, Neumann M, Vosberg S, James AR, Schroeder MP, Ortiz-Tanchez J, Isaakidis K, Schlee C, Luther M, Jöhrens K, et al. 2017. Molecular alterations in bone marrow mesenchymal stromal cells derived from acute myeloid leukemia patients. Leukemia 31: 10691078.

Vukovic M, Guitart AV, Sepulveda C, Villacreces A, O’Duibhir E, Panagopoulou TI, Ivens A, Menendez-Gonzalez J, Iglesias JM, Allen L, et al. 2015. Hif- $1 \alpha$ and Hif- $2 \alpha$ synergize to suppress AML development but are dispensable for disease maintenance. J Exp Med 212: 2223-2234.

Walkley CR, Olsen GH, Dworkin S, Fabb SA, Swann J, McArthur GA, Westmoreland SV, Chambon P, Scadden DT, Purton LE. 2007a. A microenvironment-induced myeloproliferative syndrome caused by retinoic acid receptor $\gamma$ deficiency. Cell 129: 1097-1110.

Walkley CR, Shea JM, Sims NA, Purton LE, Orkin SH. 2007b. Rb regulates interactions between hematopoietic stem cells and their bone marrow microenvironment. Cell 129: 1081-1095.

Wang L, Zhang H, Rodriguez S, Cao L, Parish J, Mumaw C, Zollman A, Kamoka MM, Mu J, Chen DZ, et al. 2014. Notch-dependent repression of miR-155 in the bone marrow niche regulates hematopoiesis in an NF- $\mathrm{kB}$-dependent manner. Cell Stem Cell 15: 51-65.

Weber JM, Forsythe SR, Christianson CA, Frisch BJ, Gigliotti BJ, Jordan CT, Milner LA, Guzman ML, Calvi LM. 2006. Parathyroid hormone stimulates expression of the Notch ligand Jagged 1 in osteoblastic cells. Bone 39: 485-493.

Winkler IG, Barbier VER, Nowlan B, Jacobsen RN, Forristal CE, Patton JT, Magnani JL, Lévesque JP. 2012. Vascular niche E-selectin regulates hematopoietic stem cell dor- 
M. Galán-Díez et al.

mancy, self renewal and chemoresistance. Nat Med 18: $1-9$.

Wöhrer S, Rabitsch W, Shehata M, Kondo R, Esterbauer H, Streubel B, Sillaber C, Raderer M, Jaeger U, Zielinski C, et al. 2007. Mesenchymal stem cells in patients with chronic myelogenous leukaemia or bi-phenotypic $\mathrm{Ph}^{+}$acute leukaemia are not related to the leukaemic clone. Anticancer Res 27: 3837-3841.

Wu JY, Purton LE, Rodda SJ, Chen M, Weinstein LS, McMahon AP, Scadden DT, Kronenberg HM. 2008. Osteoblastic regulation of B lymphopoiesis is mediated by Gs $\alpha$ dependent signaling pathways. Proc Natl Acad Sci 105: 16976-16981.

Xie Y, Yin T, Wiegraebe W, He XC, Miller D, Stark D, Perko K, Alexander R, Schwartz J, Grindley JC, et al. 2009. Detection of functional haematopoietic stem cell niche using real-time imaging. Nature 457: 97-101.

Yamazaki S, Iwama A, Takayanagi SI, Eto K, Ema H, Nakauchi H. 2009. TGF- $\beta$ as a candidate bone marrow niche signal to induce hematopoietic stem cell hibernation. Blood 113: 1250-1256.

Yamazaki S, Ema H, Karlsson G, Yamaguchi T, Miyoshi H, Shioda S, Taketo MM, Karlsson S, Iwama A, Nakauchi H. 2011. Nonmyelinating Schwann cells maintain hematopoietic stem cell hibernation in the bone marrow niche. Cell 147: 1146-1158.

Yang L. 2005. Identification of $\mathrm{Lin}^{-} \mathrm{Scal}^{+} \mathrm{kit}^{+} \mathrm{CD} 34^{+} \mathrm{Flt} 3^{-}$ short-term hematopoietic stem cells capable of rapidly reconstituting and rescuing myeloablated transplant recipients. Blood 105: 2717-2723.

Ye H, Adane B, Khan N, Sullivan T, Minhajuddin M, Gasparetto M, Stevens B, Pei S, Balys M, Ashton JM, et al.
2016. Leukemic stem cells evade chemotherapy by metabolic adaptation to an adipose tissue niche. Cell Stem Cell 19: 23-37.

Yoshihara H, Arai F, Hosokawa K, Hagiwara T, Takubo K, Nakamura Y, Gomei Y, Iwasaki H, Matsuoka S, Miyamoto K, et al. 2007. Thrombopoietin/MPL signaling regulates hematopoietic stem cell quiescence and interaction with the osteoblastic niche. Cell Stem Cell 1: 685-697.

Zambetti NA, Ping Z, Chen S, Kenswil KJG, Mylona MA, Sanders MA, Hoogenboezem RM, Bindels EMJ, Adisty MN, Van Strien PMH, et al. 2016. Mesenchymal inflammation drives genotoxic stress in hematopoietic stem cells and predicts disease evolution in human pre-leukemia. Cell Stem Cell 19: 613-627.

Zeng Z, Shi YX, Samudio IJ, Wang R-Y, Ling X, Frolova O, Levis M, Rubin JB, Negrin RR, Estey EH, et al. 2009. Targeting the leukemia microenvironment by CXCR4 inhibition overcomes resistance to kinase inhibitors and chemotherapy in AML. Blood 113: 6215-6224.

Zhang J, Niu C, Ye L, Huang H, He X, Tong WG, Ross J, Haug J, Johnson T, Feng JQ, et al. 2003. Identification of the haematopoietic stem cell niche and control of the niche size. Nature 425: 836-841.

Zhang B, Chu S, Agarwal P, Campbell VL, Hopcroft L, Jørgensen HG, Lin A, Gaal K, Holyoake TL, Bhatia R. 2016. Inhibition of interleukin-1 signaling enhances elimination of tyrosine kinase inhibitor-treated CML stem cells. Blood 128: 2671-2682.

Zhou BO, Yue R, Murphy MM, Peyer JG, Morrison SJ. 2014. Leptin-receptor-expressing mesenchymal stromal cells represent the main source of bone formed by adult bone marrow. Stem Cell 15: 154-168. 


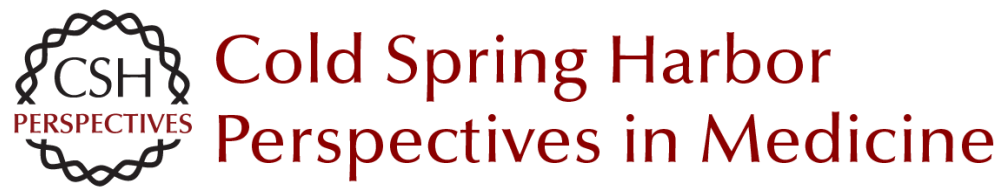

\section{The Bone Marrow Microenvironment in Health and Myeloid Malignancy}

Marta Galán-Díez, Álvaro Cuesta-Domínguez and Stavroula Kousteni

Cold Spring Harb Perspect Med 2018; doi: 10.1101/cshperspect.a031328 originally published online September 29, 2017

\section{Subject Collection Bone: A Regulator of Physiology}

\section{Mechanism of Bone Mineralization} Monzur Murshed

Neural Regulation of Bone and Bone Marrow Maria Maryanovich, Shoichiro Takeishi and Paul S. Frenette

Regulation of Bone Remodeling by Parathyroid Hormone Marc N. Wein and Henry M. Kronenberg

The Bone Marrow Microenvironment in Health and Myeloid Malignancy

Marta Galán-Díez, Álvaro Cuesta-Domínguez and Stavroula Kousteni

The Biology of Bone Metastasis

Mark Esposito, Theresa Guise and Yibin Kang

Bone Remodeling and the Microbiome Roberto Pacifici

\section{Osteoimmunology}

Kazuo Okamoto and Hiroshi Takayanagi

Multiple Myeloma and Bone: The Fatal Interaction Silvia Marino and G. David Roodman

Biology of Bone: The Vasculature of the Skeletal System

Emma C. Watson and Ralf H. Adams

Regulation of Energy Metabolism by

Bone-Derived Hormones

Paula Mera, Mathieu Ferron and Ioanna Mosialou

\section{Biology of Fibroblast Growth Factor 23: From \\ Physiology to Pathology \\ Marie Courbebaisse and Beate Lanske}

Regulation of Bone Metabolism by Sex Steroids Sundeep Khosla and David G. Monroe

For additional articles in this collection, see http://perspectivesinmedicine.cshlp.org/cgi/collection/ 